\title{
VÍRUS VÊM EM VÃO: UMA ALEGORIA DA PAN-ESCOLA QUE (NÃO) VIRÁ***
}

\author{
Antonio Miguel \\ Carlos Roberto Vianna
}

Resumo: Neste capítulo, desenvolvemos uma alegoria terapêutica sobre o problema da educação (matemática) escolar, lidando com ele como uma pandemia. $\mathrm{O}$ vírus mutante que a provoca causa vários sintomas, crenças-imagens cristalizadas, que se manifestam persistentemente desde o início dos processos modernos de escolarização: a febre disciplinar, que desfigurou e transformou práticas culturais em conteúdos verbais fixos; a febre epistêmicomentalista, que transformou os jogos de linguagem entretecidos em formas praxiológicas de vida em saberes em si, independentes das linguagens e das gramáticas ético-políticas que as orientam, o que levou a uma distinção doentia entre saber-em-si e saber-fazer com os signos de uma linguagem; a ilusão de atemporalidade e o vício determinista, que impediram de se ver as práticas de se lidar com fenômenos considerados aleatórios como práticas matemáticas, e ambas como práticas que se constituem entretecidas em diferentes formas de vida, o que impediu a educação (matemática) escolar de problematizar diretamente - isto é, sem a mediação de óculos disciplinares - as práticas culturais que se realizam em diferentes formas de vida. Possíveis modos de se lidar com essa pandemia são pensados em um quadro pós-pandêmico imaginário em que a escola poderia se transformar em uma pancomunidade virtual voltada à problematização terapêutica de diferentes formas de vida e das práticas culturais que nelas se realizam, visando ao propósito de se formar guardiões de formas democráticas, solidárias, igualitárias e não-racistas de organização das vidas em diferentes formas de vida. Nessa pan-escola que (não) virá, a educação matemática desconstruída passa a ser vista como um conjunto de jogos de linguagem orientados por propósitos normativos, cujos efeitos e afetos - nem sempre desejáveis e previsivelmente controláveis - sobre as vidas e as formas de vida, se abrem igualmente à problematização bioético-política.

Palavras-chaves: Pan-escola; Práticas culturais; Formas de vida; Problematização terapêutica; Educação matemática escolar desconstruída.

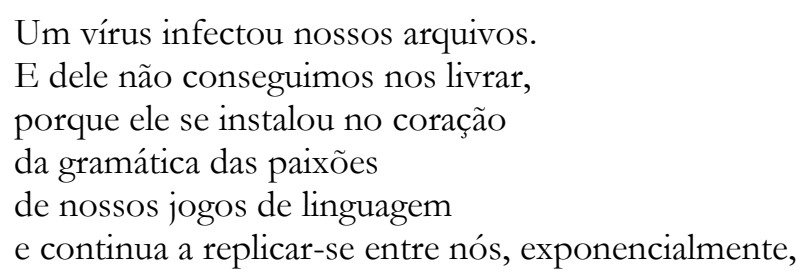

\footnotetext{
* DOI - 10.29388/978-65-86678-51-2-0-f.763-778

** Este texto foi originalmente publicado na referência que se segue e foi devidamente autorizado pelos editores da revista a ser republicado nesta obra coletiva: MIGUEL, A.; VIANNA, C. R. Vírus vêm em vão: uma alegoria da pan-escola que (não) virá. Revista Latinoamericana de Etnomatemática, v. 13, n, 1, p. 6-28, 2020. DOI: 10.22267/relatem.20131.42. Disponível em: (https://www.revista.etnomatematica.org/index.php/RevLatEm/article/view/589/496), Acesso em 16 nov. 2020.
} 
como canções e epidemias ${ }^{1}$.

\section{Language is a virus ${ }^{2}$ !}

2. Meu caro amigo, me perdoe, por favor, se eu não lhe faço uma visita, mas como agora apareceu um portador, mando notícias neste artigo. Já nem se joga o futebol, mas inventam aulas a distância para as crianças e até ensaiam voltar a mandá-las para escolas, mesmo com as pessoas precisando fazer piruetas pra cavar um ganha-pão, e todos vivendo só de birra e dando duro pra segurar esse rojão! $!^{3}$

3. Meu caro amigo, quem poderia imaginar uma situação como esta? A UNICAMP foi uma das primeiras universidades do país a suspender as atividades no ínício de março. O Secretário de Saúde de Campinas, que é também professor da UNICAMP, nos aconselhou a não colocar o nariz para fora de casa. $\mathrm{Na}$ enxurrada de mensagens via WhatsApp já recebi pelo menos três "teorias explicativas" da pandemia: uma teoria conspiratória de que o vírus teria sido criado em um laboratório na China, uma outra, igualmente conspiratória, de que teria sido fabricado pelos Estados Unidos, ambas em nome da guerra pela reorganização geopolítica das nações; e, uma terceira teoria, que defende que a pandemia teria tido origem na China, mas devido a causas naturais provocadas por hábitos culturais alimentares de uma parte da comunidade.

4. A matemática da pandemia é modelada de modo muito simples. Trata-se de uma função exponencial, compreensível desde que se tenha aprendido a multiplicar e a observar o crescimento de multiplicações sucessivas. Mas essa observação não é um hábito sequer entre professores de matemática! Suponhamos que a cada 3 dias (t), o número de pessoas contaminadas $(\mathrm{N})$ dobra, a equação que fornece o número de casos é $\mathrm{N}=$ raiz cúbica de 2 (isto é, aproximadamente 1,26) elevada ao expoente correspondente ao número de dias. Exemplo: depois de 9 dias da constatação do primeiro caso, o número de pessoas infectadas seria em torno de 8; depois de 12 dias, em torno de 16. Ou seja, à medida em que o tempo cresce em progressão aritmética de razão 3, o número de contaminações cresce em progressão geométrica de razão 2. Esse é um modelo básico que pode nos dar uma ideia de como se propaga essa doença, e essa é a razão para que ela tenha sido declarada uma pandemia.

5. Está certo quem diz: essa pandemia é uma invenção! No dia 11 de março de 2020, a Organização Mundial da Saúde (OMS) declarou oficialmente a pandemia de coronavírus. Tedros Adhanom Ghebreyesus, diretor-geral da OMS, afirmou: "Pandemia não é uma palavra para ser usada à toa ou sem cuidado". [...] "A descrição da situação como uma pandemia não altera a avaliação da OMS da ameaça representada por esse vírus. Isso não muda o que a OMS está fazendo nem o que os países devem fazer"’4. Embora pareça cartorial, essa é uma decisão tomada a partir de

\footnotetext{
${ }^{1}$ Colagem entre o aforismo de Wittgenstein (s/d, IF-115) e versos da letra da canção Caça à raposa de Aldir Blanc e João Bosco. A letra completa da canção está disponível no site (https://www.cifraclub.com.br/joao-bosco/caca-raposa/letra/), visitado em 10 de maio de 2020. Nesta e em outras referências à obra de Wittgenstein, será adotado o padrão internacional de remissão aos aforismos e não às edições dos livros.

2 Título e refrão da canção Language is a virus de Laurie Anderson. A letra completa da canção está disponível no site (https://www.letras.mus.br/laurie-anderson/288297/) visitado em 10 de maio de 2020.

${ }_{3}^{3}$ Adaptação da letra de Meu Caro Amigo de Chico Buarque de Holanda. A letra completa da canção está disponível no site (https://www.letras.mus.br/chico-buarque/7584/), visitado em 10 de maio de 2020.

${ }^{4}$ Trecho do pronunciamento do diretor-geral da Organização Mundial da Saúde (OMS), Tedros Adhanom Ghebreyesus, no dia 11 de março de 2020, em Genebra, na Suíça, segundo a matéria publicada nesta mesma data no site da Organização
} 
critérios objetivos e não seria possível, por exemplo, declarar que o câncer é uma pandemia, ou que existe uma pandemia de fome... embora as duas coisas - câncer e fome - existam em todo o planeta e mereçam a atenção e o cuidado de todas as pessoas.

6. - Até há pouco tempo, se discutia se um vírus é um ser vivo. Se você pensar em um vírus como uma bola de tênis, o ser humano deveria ter perto de $800 \mathrm{~km}$ de altura, algo como a distância entre a cidade de São Paulo e Goiânia. - Você está querendo dizer que a altura de um ser humano seria um critério vital confiável para se traçar uma fronteira entre os seres vivos e os seres inanimados? Não seria este um critério vital demasido humano, demasiado humanista? - Eu só quis dizer que um vírus é bem menor do que uma célula, e que houve tempo em que o padrão de "ser vivo" era definido em comparação com as células do corpo humano. - Em outras palavras, você quis dizer que houve um tempo em que a morfologia dos seres vivos não era explicada pela sua derivação da morfologia dos seres inertes, inorgânicos. Talvez, porque, postular um laço de continuidade entre essas duas formas de vida seria rebaixar o humano a níveis supostamente inferiores de vida. - Pelo menos tem sido esta, desde tempos remotos, a opção exclusiva das teorias científicas organicistas de explicação da emergência das formas de vida, qual seja, distinguindo-as das formas de ser dos seres ditos inertes, inorgânicos. - Ainda que cada vez mais essas explicações venham contribuindo para tornar indistinta essa fronteira. Pasteur sugeriu não serem as células, isto é, as moléculas da vida, contrariamente às moléculas do mundo mineral, assimiláveis às suas imagens em um espelho. - O que ele quis dizer com isso? - Pense, por exemplo, no DNA, um composto orgânico cujas moléculas orientam o desenvolvimento de todos os seres vivos e também alguns tipos de vírus. A forma da molécula de DNA assemelha-se a uma hélice dupla voltada para a direita, mas a sua imagem num espelho aparece como uma hélice dupla voltada para a esquerda. Já as moléculas simétricas dos minerais não gozam dessa propriedade e as moléculas de todo ser que pode ser fabricado com moléculas simétricas minerais continuam sendo simétricas. - Continua sendo um critério normativo, ainda que empiricamente observável, para se distinguir vida de não vida. - E aqui, a norma natural parece ser a de que a vida teria sido levada a optar por formas assimétricas orientadas para a direita, em nítido contraste à simetria dos cristais líquidos. - Parece que a vida prefere a desordem à ordem... - Mais radicalmente, alguns cientistas vêm falando dos seres vivos como estruturas dissipativas produzidas através de processos aleatórios ${ }^{5}$. - E o que eles querem dizer com isso? - Que vida é algo que participa da termodinâmica do irreversivel, isto é, de reações químicas que se processam de modo irreversível em ambientes fluidos. Pense, por exemplo, numa gota de tinta rubra dispersando-se progressivamente na água contida num copo. Depois de um certo tempo, a cor da água ficará completamente uniforme, indicando que a tinta não mais se concentra em apenas alguns locais da água. Entretanto, em reações num ambiente fluido não dissipativo, ocorreria exatamente o

\footnotetext{
an-Americana de Saúde (OPAS), e acessado em 10 de maio de 2020: (https://www.paho.org/bra/index.php?option=com_content\&view=article\&id=6120:oms-afirma-que-covid-19-e-agoracaracterizada-como-pandemia\&Itemid $=812$ ).

5 Allan Turing, em artigo de 1952 intitulado As bases químicas da morfogênese, conjecturou que as formas vivas resultariam da associação entre reação química e difusão de matéria. Ilya Prigogine, na teoria das estruturas dissipativas, usa essa associação.
} 
oposto desse tipo de distribuição uniforme da tinta na água. - Você está querendo dizer que, visualmente, a morfogênese de uma vida seria um processo de distribuição não uniforme, um processo caótico que não poderia ser visualmente descrito por uma curva normal? - $\mathrm{O}$ que estou querendo destacar é o poder criativo dos processos aleatórios na produção de vida de diferentes formas de vida. - Mas dizer isso não é o mesmo que dizer que vidas se produzem aleatoriamente? - É o mesmo que dizer que vidas se produzem no caos do acaso. E que, portanto, um vírus também se produz no caos do acaso. - E que, portanto, um vírus é também um ser vivo. - O que importa? - Importa que vírus, justamente por serem corpos que afetam vitalmente corpos humanos, são também corpos que importam 6 .

7. Decisões são coisas importantes? Sim, decisões são coisas importantes! Decidimos o que é "ser vivo", decidimos o que é "pandemia", decidimos o que é "doença", ... e em certas situações fomos levados a decidir quem deve viver ou morrer, quem deve ter acesso a um respirador e quem deve sofrer os sintomas da síndrome respiratória aguda... Decisões são questões políticas. Decisões são, também, questões matemáticas. É possível tomar decisões ótimas! Mas é necessário ter em conta que qualquer processo de otimização é definido a priori por interesses e valores. Exemplo notável afirmado por um Ministro da Saúde no Brasil: se comprarmos respiradores demais agora, depois da pandemia eles serão inúteis.

8. I can't breath!

9. Não há um lado de fora. Do lado de fora, falta o ar vital. - O que acontece com as vidas do lado de fora da escola? - Nada sabemos! A escola colonizadora e, portanto, racista, inventou-se para modelar o ar vital que vem de fora e não para ser contaminada por ele. - Você quer dizer que a nossa escola já havia decidido pela reclusão antes das pandemias? - Quero dizer que, para ela, o ar de fora é um vírus!

10. Muitas decisões são tomadas a partir de informações. Algumas decisões podem ser muito simples: você acha que o Sol ainda existirá amanhã? Claro que sim! Você nem cogita que o Sol possa deixar de existir entre hoje e amanhã, afinal... ele sempre esteve aí... Será que coisas como $A$ Escola sempre estiveram aí? Mas você acha que amanhã irá chover? Algumas vezes chove, outras não... há períodos de seca... Fazemos previsões sobre o clima a partir de dados coletados sistematicamente durante anos. Inventamos uma disciplina: a estatítica.

11. Estatística é matemática? Estudar a pandemia sob o aspecto de tomada de decisão em relação a políticas de saúde pública, ou a políticas de educação pós-pandêmicas, tem a ver com estatística, com matemática, com etnomatemática, com jogos de linguagem orientados por propósitos normativos? Tomar decisões tem algo a ver com matemática? E tomar a decisão ótima?

\footnotetext{
${ }^{6}$ Segmento baseado nas entrevistas de Yves Bouligand e Christian Vidal a Émile Nöel (1996, p. 69-89).

7 “I can't breath!" (Não consigo respirar!). Últimas palavras reiteradas por George Floyd, 46 anos, vítima fatal do racismo e da brutalidade policial, na noite de 25 de maio de 2020, em Minnesota, Estados Unidos. Milhares de pessoas em todo o mundo deixaram de ter a possibilidade de respirar devido a decisões de otimização como a do referido Ministro da Saúde do Brasil. ${ }^{8}$ Wittgenstein (s/d, IF-103), itálicos nossos: "O ideal, no nosso pensamento, fixa-se imutavelmente. Você não pode sair dele. Tem que voltar sempre a ele. Não há um lado de fora. Do lado de fora falta o ar vital. - De onde vem isso? O ideal assentase, por assim dizer, como óculos sobre o nosso nariz, e, o que enxergamos, vemos através deles. Não nos ocorre sequer a ideia de removê-los". Não há uma realidade exterior ao próprio pensamento em que se possa respirar, dado que só se respira $\mathrm{o}$ ar viciado da própria prisão em que se encontra o pensamento.
} 
12. Como as teorias acerca da tomada de decisões ótimas afetam os comportamentos das pessoas que desconhecem tais teorias? E se elas as conhecessem, modificariam os seus comportamentos?

13. O paraíso é exatamente como onde você está agora, só que muito muito melhor?.

14. A variação do número de casos de infecção pelo vírus ao longo do tempo, em uma determinada comunidade humana, é um fenômeno aleatório? Ou ele pode ser visto como aleatório apenas se o vírus fosse visto como um ser que toma decisões ótimas?

15. Se a conjectura de uma produção intencional da pandemia com o propósito de motivar uma reorganização da ordem geopolítica mundial fosse confirmada, estaríamos diante de um novo tipo de guerra no qual se faria um uso intencional do acaso na promoção de um genocídio no qual haveria uma margem de controle para a escolha de "tipos" mais expostos aos fatores de risco. Por exemplo, seria hoje a massa mundial de velhinhos aposentados e improdutivos que incomoda os cofres das previdências e; amanhã, a massa de deficientes físicos e mentais; depois... Depois? Quais os limites?

16. Que importa quem organiza ou toma a decisão ótima acerca do modo como se comporta um fenômeno? Que importa se o fenômeno é ou não aleatório?

17. Black lives matter! ${ }^{10}$

18. - O que acontece com as vidas do lado de fora da escola? - Nada sabemos! A escola colonizadora e, portanto, racista, inventou-se para modelar o ar vital que vem de fora e não para ser contaminada por ele. - Você quer dizer que a nossa escola já havia decidido pela reclusão antes da pandemia? - Quero dizer que, para ela, o ar de fora é um vírus!

19. Pense na curva desenhada sobre um papel no chão pela tinta que jorra de uma lata furada e presa por uma corda a um ponto no teto de uma sala. Essa lata recebe um impulso inicial e passa a se mover ritmicamente, projetando sobre o papel no chão um fluxo contínuo de tinta que faz um desenho... Será esse desenho uma figura aleatória? Esse movimento não é interpretado como regular ou periódico somente a partir da visão da curva traçada pela tinta no chão? O conjunto "lata de tinta furada suspensa por uma corda fixada no teto" toma a decisão ótima de traçar uma curva periódica no chão? Ou é o modo humano de realizar a experiência desta - e não de outra maneira - que já teria tomado a decisão ótima de tornar não aleatório o movimento da lata suspensa no ar?

20. O que importa se o fenômeno da variação da contaminação pelo vírus ao longo do tempo é ou não um fenômeno aleatório? O que importa se as pessoas que se contaminam ou não pelo vírus se comportam de modo indiferente ou se tomam a melhor decisão no modo de se comportarem em relação a essa variação? O que importa não é um é ou não é, mas que as variações não variam da mesma maneira... Importa que há tantos modos de variações quantos são os fenômenos vistos como aleatórios.

21. Uma distribuição de probabilidades se chama normal devido à sua capacidade de modelar um grande número de fenômenos naturais. A curva normal é natural?

\footnotetext{
${ }_{9}$ Primeiros versos da letra da música Language is a vírus de Laurie Anderson, a que fizemos referência na nota de rodapé 2. ${ }^{10}$ Black Lives Matter é um movimento ativista internacional que organiza protestos em torno das mortes de negros causadas por policiais e de questões mais amplas de discriminação racial.
} 
22. Aqui estão curvas que representam três diferentes distribuições normais de probabilidades $^{11}$ :

23.

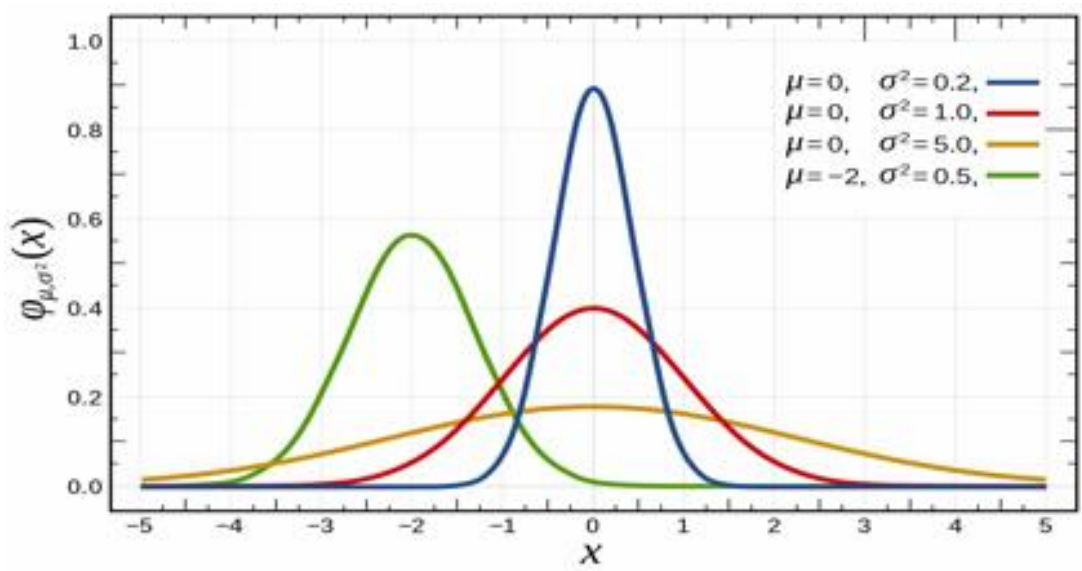

24. Sinto medo de um dia achar a tristeza normal ${ }^{12}$.

25. Se a lata de tinta suspensa no ar seguisse o movimento de uma formiga andando sobre o papel, o traçado do fluxo de tinta seria aleatório? E se, surpreendentemente, ao seguir a formiga, a lata de tinta fizesse sobre o papel o mesmo desenho que fez ao ser acionada como um pêndulo? Seria mais ou menos aleatório? Qual seria a nossa definição de aleatório? Como manteríamos alguma coerência para definirmos o que é vida? E o que é uma pandemia?

26. Em uma pesquisa conduzida por Jodelet (2005) sobre a representação social da loucura em uma comunidade rural francesa transformada em instituição psiquiátrica aberta, observou-se que os integrantes considerados sãos na referida comunidade lavavam as suas roupas e pratos separadamente das roupas e pratos dos doentes mentais, ainda que em suas declarações verbais prestadas à pesquisadora, tais pessoas que se consideravam sãs não vissem a doença mental como contagiosa. Em outras palavras, embora aquelas pessoas dissessem não acreditar ser a doença mental contagiosa, elas se comportavam como se ela o fosse. E se a doença mental fosse provocada por um vírus? Seria contagiosa? Seria contagiosa independentemente da crença das pessoas?

27. Que relações subsistem entre crenças, saberes e comportamentos?

28. Façamos de conta que um vírus chamado disciplinarização propagou-se no terreno das práticas e no território escolar. Ele não mata, mas todos os que tomam contato com ele se tornam suas vítimas. Você se vê como portador desse vírus? Sintomático ou assintomático?

29. Um grupo denominado G20 declarou oficialmente: O vírus não respeita fronteiras! Disseram: "O combate a esta pandemia exige uma resposta global com espírito de solidariedade, que seja transparente, robusta, coordenada, de larga escala e baseada na ciência. Estamos fortemente comprometidos a apresentar uma frente unida contra essa ameaça comum". Comunidades humanas constróem fronteiras com base em

\footnotetext{
11 As imagens não serão referidas "dentro do texto", elas são entendidas como parte do texto. A fonte da imagem é a Wikipedia: (https://www.pt.wikipedia.org/wiki/Distribuição_normal). Acesso em 20 maio 2020.

12 Segmento composto a partir de verso da canção Recado de Renato Teixeira, cuja letra completa pode ser acessada no site (https://www.letras.mus.br/renato-teixeira/recado/), Acesso em: 20 maio 2020.
} 
vínculos identitários: geopolíticos, praxiológicos, linguísticos, étnicos, afetivos, culturais etc. Mas comunidades não bumanas parecem agir à revelia de tais traços identitários, afinal... essas são "necessidades humanas", não são? Seriam mesmo?

30. No primeiro parágrafo do verbete Aritmética Política da Enciclopédia, Diderotafirma: "Aritmética política é aquela cujas operações têm por finalidade as pesquisas úteis à arte de governar os povos, tais como as do número de homens que habitam um país, da quantidade de alimento que devem consumir, do trabalho que podem fazer, do tempo que têm a viver, da fertilidade das terras, da frequência dos naufrágios etc." 13 No último parágrafo do mesmo verbete Diderot nos remete a práticas diversas que, apenas no século 19 - com base na constatação de semelhanças de família entre os problemas que tais práticas mostraram-se adequadas em responder -, seriam nomeadas estatísticas: “[...] as práticas de jogos de azar, que haviam sido analisadas no livro $A$ análise dos jogos de azar, atribuído ao senhor Montmort; práticas de seguros de vida visando ao recebimento de rendas vitalícias; práticas de constituição de fundos comuns ou de poupança coletiva para fins diversos, descritas e analisadas na obra Sobre as rendas vitalicias e fundos comuns, atribuída ao senhor Parcieux; as práticas de cômputo e análise de tábuas mortuárias com o propósito de se calcular índices de esperança de vida ou de morte dos cidadãos ingleses, no século 17, realizadas pelo demógrafo britânico John Graunt (1620-1674) e publicadas na obra de 1662 intitulada Natural and Political Observations upon the Bills of Mortality e estudos semelhantes realizados pelo astrônomo e matemático britânico Edmond Halley (1656-1742) publicados na obra intitulada An Estimate of the Degrees of the Mortality of Mankind, de 1693, na qual apresenta a primeira tábua de mortalidade cientificamente construída"14. Estatísticas são, afinal, aritméticas políticas definidas por necessidades humanas?

31. Olhando a curva traçada no chão pela tinta que jorra da lata suspensa por uma corda fixada ao teto e pensando na história da estatística: foram os estudos científicos produzidos com base no cômputo, análise e tentativas de se ver regularidade na ocorrência de eventos até então vistos como casuais como, por exemplo, as mortes por vários tipos de doenças registradas e classificadas em tábuas de mortalidade na Inglaterra do século 17, que levaram ao surgimento de várias teorias de probabilidades ao longo dos séculos 18, 19 e 20. É isso que permite, por exemplo, estudar, em nossos dias, o comportamento do vírus Covid 19 e traçar as curvas da quantidade de pessoas infectadas em função do tempo para tentar fazer uma gestão estatística da pandemia? Mas não seria possível também ver essa experiência com um olhar que nos levaria a dizer que "o acaso é um artista", ou que "Deus é um artista", ou que "os deuses agem como artesãos"? Ou, talvez, no caso do Covid 19, preferíssemos dizer: "O diabo age como um assassino". Mera questão de preferências? Escolhas?

32. Se vemos uma bela curva fechada que se auto-intersecta periodicamente e essa curva é traçada no chão pela tinta que jorra de uma lata furada suspensa por uma corda e balançando livremente no ar, então, essa curva foi desenhada porque certamente existe 
uma expressão algébrica que descreve o movimento da lata em função do tempo. Mas, mesmo que esta expressão exista e possa ser escrita, ela não explica o movimento da lata, ela apenas o descreve.

33. A visão moderna do mundo está fundada na ilusão de que as chamadas leis naturais sejam explicações dos fenômenos naturais. Os modernos detêm-se diante das leis naturais como que diante de algo intocável, tal como se detinham os antigos diante de Deus e do Destino. O destino é a antítese da lei natural, ela é algo que se pretende sondar e utilizar, o destino não. Eu sou do subúrbio e sei que o destino pra nós é bem simples não vai variar ${ }^{15}$.

34. Importa se um vírus age intencionalmente? O que nos importa não é que o seu modo de agir nos afeta? Vamos condenar nosso antropocentrismo?

35. Descobrir as regras que orientam o jogo de linguagem de um vírus, o modo como ele nos afeta e nos infecta é descrever a sua gramática, a sua matemática. Descobrir as regras que orientam o jogo de linguagem de um vírus, o modo como ele nos afeta e nos infecta é descrevê-lo na nossa gramática, na nossa matemática.

36. A linguagem é um vírus. E um vírus só nos afeta e infecta com os signos de uma linguagem.

37. O vírus é humano ou não humano? Se só humanos transmitem o vírus para outros humanos, a pandemia é uma produção humana. Diz o vírus: minto se disser não ser humano. Diz um humano: minto se disser não ser um vírus. Sou o paradoxo do mentiroso, conclui o vírus.

38. Imagine um dispositivo que em lugar de seis faces tivesse tantas faces quantas fossem as formas como os seres humanos, em interaçao com os demais seres naturais, organizam as suas vidas. Imagine que a quantidade de faces desse dispositivo aumentasse sempre que novas formas de vida surgissem, mas não diminuísse quando formas de vida se tornassem obsoletas ou se extinguissem. Indo além, agora imagine que cada face desse dispositivo aciona um biperlink que nos conecta a um filme da história da forma de vida correspondente a essa face. Um modo possível de organizar a educação básica pós-pandêmica consistiria em explorar os jogos de linguagem de cada face desse dispositivo, bem como analisar e projetar possibilidades de vidas em aberto nas incertezas inexploradas de hiperlinks e filmes, formas de vida, por constituir.

39. Um vírus não se comporta nem se transmite. Os modos como as comunidades de animais, humanos, reagem e descrevem as suas variações de comportamento são atribuídas ao vírus, dizendo-se que há dele, por exemplo, uma transmissão comunitária. Em outras palavras, um vírus irá se comportar de tantas maneiras quantas forem as descrições comunitariamente acordadas do seu comportamento. Pode-se dizer que é o caso da união entre uma forma de vida humana e virótica. Para uma comunidade humana, o comportamento desejável do vírus poderia ser aquele que permitisse criar práticas de comportamentos humanos adequados à preservação do maior número de vidas humanas dessa comunidade. Para outra comunidade, o comportamento considerado adequado poderia ser o de acelerar o processo de

\footnotetext{
${ }^{15}$ Composição de dois aforismos de Wittgenstein (2002, TLP 6.371) com outro aforismo de (WITTGENSTEIN, 2000, p. 93) e um verso da canção Recado de Renato Teixeira, a que fizemos referência na nota de rodapé 12.
} 
transmissão do vírus, buscando alcançar o maior número de mortos no menor tempo possível. Existem infinidades de acordos possíveis e a decisão ótima é uma decisão política. Seja qual for a decisão, a adequação dos comportamentos só ocorrerá se houver adesão e respeito às regras do acordo estabelecido. Descrito o comportamento do vírus, não será ele que irá quebrar o acordo estabelecido entre as duas formas de vida.

40. Com o que poderia se parecer uma escola pós-pandêmica? Com uma outra escola normalizada, normatizada, otimizada? E como poderia ser a educação matemática nessa escola otimizada? - Basta de otimizações e otimismos! O sonho (deles) acabou! E ninguém vai dormir nosso sonbo! Pra que tantos planos? Tantas vezes eu quis ficar solto, como se fosse uma lua a brincar no teu rosto ${ }^{16}$. - Talvez, devêssemos então indagar: já não é hora de pensar um mundo sem escolas? - Talvez, só assim as pessoas aprendam aquilo que a escola nunca lhes quis ensinar: que não é ela que produz a desigualdade social, econômica e política entre os cidadãos de uma nação ou entre as nações, e que não é ela que poderá produzir sociedades em que a democracia política, econômica e social global venha a ser a norma e o normal.

41. - Você acredita que a riqueza das nações depende mesmo da existência de uma educação escolar concorrencial, normalizada, normatizada e objetivamente eficaz? Não se trata de uma crença, mas de um saber que as estatísticas mostram. - As estatísticas também não poderiam mostrar que é a educação escolar normalizada, normatizada e objetivamente eficaz que depende da riqueza das nações? Elas não poderiam mostrar também que foi o desejo de perpetuação da riqueza desigual entre as nações que produziu essa imagem colonizadora de educação escolar?

42. São as estatísticas que tomam decisões políticas ótimas por nós ou somos nós que podemos tomar decisões politicas ótimas com base nas estatísticas?

43. - As estatísticas da pandemia poderiam levar-nos a tomar decisões políticas ótimas no sentido de livrar a humanidade do vírus que produziu a persistente imagem de vida econômica que cria e sustenta a pobreza e a desigualdade? - Você está querendo dizer que a pandemia, que levou o sistema à paralisia, poderia nos salvar de tudo isso? Veja! A década da última chance - último estágio de aquecimento global, aumento da desigualdade de renda - estava nos levando a uma rota suicida... - E que outras formas de vida econômica o vírus nos mostra? - Formas desmilitarizadas de vida que garantam zero emissão líquida de carbono, zero concentração de riqueza, zero desemprego, zero lucro pessoal e nada de maximização de lucros. Os empreendimentos que visarem a lucros devem se tornar social e ambientalmente responsáveis. Redesenhar todo o sistema financeiro de modo que ele passe a financiar as pessoas mais pobres e vulneráveis. Todos os desempregados receberiam ativos para começar suas empresas. O sistema educacional seria redesenhado para preparar ${ }^{16}$ Versos da canção Muito estranho (Cuida bem de mim), de Claudio Rabello e Dalto Medeiros, cuja letra completa pode ser
acessada no site (http://www.beakauffmann.com/mpb_m/muito-estranho.html), visitado em 20 de maio de 2020. 
os jovens para começar suas vidas como empreendedores ${ }^{17}$. - No going back talks! ${ }^{18}$. Mas, ainda que a economia pudesse funcionar assim, ver as pessoas como empreendedoras e o sistema educacional a serviço da formação de empreendedores, não seria manter o desejo do neoliberalismo colonizador como propósito da escolarização?

44. - Seria possivel anular o poder do vírus colonizador na escola e com escolas, sem desinstalálo de nossos arquivos, dos arquivos escolares, de nossos arquivos vitais? - Antes mesmo dessa pandemia, ele já havia se apossado de nossas terras, de nossos braços, de nossos discursos, de nossas formas de vida, de nossas vidas, de nossos corpos. Quero dizer: seria possível anular o poder do vírus colonizador com escolas? - Talvez, nem sem elas...

45. Haverá um amanhã que anuncie uma pan-escola? Se dizemos "Isso provavelmente ocorrerá", essa proposição não é verificada pela ocorrência e nem falsificada pela não ocorrência do fenômeno em questão. Nossa experiência parece concordar sempre com uma probabilidade que calculamos antecipadamente... Isso não deveria fazer sentido, mas é como procedemos: se a experiência concorda com o cálculo, o cálculo é justificado pela experiência e, naturalmente, não é um elemento a priori que é justificado, mas sim, as suas bases, que são a posteriori. Mas estas bases têm de ser certas regras naturais que considero a base de meu cálculo e são elas que são confirmadas, e não o cálculo... O cálculo da probabilidade transforma a regra natural, é o veículo pelo qual percebemos e aplicamos a regra natural. Se, por exemplo, lanço um dado, posso aparentemente prever a priori que 1 ocorrerá uma vez a cada seis lances, e isso, então, pode ser confirmado empiricamente. Mas, não é o cálculo que confirmo pelo experimento, e sim, a regra natural que o cálculo de probabilidade pode me apresentar de outras formas. No caso do lançamento do dado, a regra natural assume a forma de que é igualmente provável que cada um dos seus lados seja o lado virado para cima, e é essa a regra que testamos ${ }^{19}$. Quais as regras em jogo para testar a pan-escola?

46. Clicar sobre um hiperlink no ato de leitura de um texto digital é um ato que pode ser visto como uma prática cultural de deslocamento espaçotemporal de um espaço-tempo $A$ a um espaço-tempo B, que se pratica sob a orientação da gramática de um jogo de linguagem - no caso, a gramática que orientou a produção do jogo de signos do software computacional criado para essa finalidade - que se joga entretecido com a gramática de uma forma de vida, no caso, a que orienta a organização da vida no campo praxiológico vital cibernético, desde que: a) a palavra espaço que compõe o substantivo composto espaço-tempo seja significada como hiperespaço, isto é, como uma Rede Mundial de Computadores (World Wide Web) interligados e disponibilizados na Internet, através da qual um usuário localizado em qualquer parte do globo, por intermédio de um dispositivo computacional pessoal, pode acessar arquivos de vídeos, de áudios, de

\footnotetext{
${ }^{17}$ Neste segmento, a conversa entre as vozes está baseada na entrevista que o economista Muhammad Yunus, nascido em Bangladesh e vencedor do Prêmio Nobel da Paz em 2006, concedeu ao jornal Folha de São Paulo em 31 de maio de 2020. Fonte da entrevista no siste seguinte, acessado em 20/05/2020:

(https://www1.folha.uol.com.br/mercado/2020/05/pandemia-tirou-mundo-de-rota-suicida-do-sistema-economicotradicional-diz-nobel-da-paz.shtml?utm source=whatsapp\&utm medium=social\&utm campaign=compwa).

${ }_{18}$ Não bá como voltar para tras - Plano de recuperação para um novo mundo: foi este o nome do debate promovido pela Yunus Negócios Sociais, no Brasil, para discutir o mundo pós-pandemia. O debate ocorreu nos dias 13, 14, 15 e 18 de maio de 2020 e pode ser integralmente acessado no Youtube.

${ }_{19}$ Comentário baseado em Wittgenstein (2005, OF-232).
} 
imagens e/ou de textos escritos em qualquer língua nativa que estiverem associados ao referido hiperlink; b) a palavra tempo que compõe o substativo composto espaçotempo seja significada como a duração da realização dessa prática do modo como ela é diretamente percebida, sentida ou vivenciada pelas pessoas que a realizam, independentemente do fato da duração da realização de tal prática poder ou não ser medida e registrada por artefatos tecnológicos utilizados como padrões de medição de duração de um evento.

47. Suponha que na forma cibernética de vida você clica sobre a palavra hiperlink e ela é, de fato, um hiperlink que lhe envia a um texto que diz "[...] biperlink é uma referência dentro de um documento em bipertexto - isto é, um programa informático utilizado para visualizar e criar esse documento - que lhe remete a outras partes desse documento on a outro documento" 20 . Ao fazer isso você realizou, simultânea e diretamente, duas práticas conjugadas com base na gramática praxiológico-normativa que orienta modos significativos de agir na forma cibernética de vida: uma prática normativa de deslocamento espaçotemporal de um texto a outro texto e uma prática normativa de aprendizagem interativa que lhe esclareceu um modo de significar a palavra biperlink, isto é, um modo inequivoco de saber-fazer com a palavra biperlink com base na gramática praxiológico-normativa que orienta os usos significativos de signos fonêmicos e grafêmicos na língua portuguesa. - Mas, quem realizou indiretamente a prática de esclarecimento desse uso da palavra hiperlink? E como o ato de clicar sobre a palavra hiperlink possibilitou realizar uma prática de deslocamento espaçotemporal de um texto a outro na forma cibernética de vida? - É preciso reconhecer que essas duas práticas conjugadas que você pode realizar diretamente, e que lhe permitiriam esclarecer esse uso, só são possíveis porque duas outras práticas teriam sido anteriormente realizadas por outros navegadores da forma cibernética de vida. E assim sucessivamente. Esse foi o paradoxo de todos os dicionários já criados, e dos que estão por criar.

48. Na pan-escola iríamos problematizar as relacões entre linkar, ligar e lexia? ${ }^{21}$

49. Mas o funcionamento - e o financiamento - de uma pan-escola não dependeria, econômica e ecologicamente, daquelas terras raras... daqueles metais... daqueles minérios... daqueles seres inorgânicos... daquelas formas de vida ditas inertes que dão vidas a computadores e a outros dispositivos eletrônicos?

50. Acionar o Código de Endereşamento Postal (CEP) de uma correspondência com o propósito de fazê-la chegar ao seu destinatário é um ato que pode ser visto como uma prática cultural de deslocamento espacotemporal de um espaço-tempo $A$ a um espaço-tempo $B$ que se pratica sob a orientação da gramática de um jogo de linguagem - no caso, a gramática ou conjunto de regras que orientou a produção do jogo de signos do CEP - que se joga entretecido com a gramática de uma forma de vida, no caso, a que orienta a organização da vida no campo praxiológico vital dos correios, desde que: a) a palavra espaço que compõe o substativo composto espaço-tempo seja significada como a porção geopraxiológica requerida para a realização dessa prática; b) a palavra tempo que compõe o substativo composto espaço-tempo seja significada como a duração da realização dessa prática do modo como ela é diretamente percebida, sentida ou

\footnotetext{
${ }^{20}$ Fonte da citação, verbete "hyperlink" da wikipedia: (https://pt.wikipedia.org/wiki/Hiperligação), acessada em 20 de maio de 2020.

${ }^{21}$ Segmento evocado por Barthes (2002).
} 
vivenciada pelas pessoas que a realizam, independentemente do fato da duração da realização de tal prática poder ou não ser medida e registrada por artefatos tecnológicos utilizados como padrões de medição de duração de um evento.

51. Acionar o Código de Endereçamento Postal (CEP) de uma correspondência com o propósito de se ensinar a estudantes de uma escola o conjunto de regras que constituem a gramática do jogo normativo de linguagem do CEP, a fim de se dar significado a um conjunto de práticas realizadas pelos Correios, é realizar uma prática cultural de ensino que se realiza sob a orientação da gramática de um jogo pedagógico de linguagem entretecido com a forma de vida escolar, isto é, produzido por esta forma de vida para cumprir os propósitos sociais de ensino, aprendizagem e problematização de modalidades particulares de práticas culturais de deslocamento, orientação, localização e rastreamento geográfico-espaciais.

52. A filosofia não altera o uso efetivo da linguagem; o que ela pode conseguir, em última instância, é descrevê-lo. A filosofia, portanto, não pode fundamentar o uso efetivo da linguagem, ela deixa tudo como está2 .

53. Um vírus, ao disseminar práticas de terrorismo comunicativo, contamina irreversivelmente a confiança epistemológica nas conhecidas práticas de aprendizagem interativa que realizamos na forma cibernética de vida. Esse vírus contamina mesmo a nossa confiança epistemológica? Se ele o fizer, alcançará o estatuto de vírus epistemológico e destruirá a confiança que deveríamos depositar na proposição "Um saber-fazer não é a confiança que depositamos em um saber-fazer".

54. Uma fake newss é a enunciação de uma mentira. Aprender a produzir fake news é aprender a mentir. Entretanto, aprender sobre fake news é aprender a duvidar de enunciados em determinadas circunstâncias. Mas como podemos desconfiar de um enunciado que tenha sido construído de modo a parecer verdadeiro? Como podemos desconfiar de um enunciado que tivesse sido construido a partir das nossas confianças epistemológicas? Como podemos distinguir uma fake news, uma mentira, de uma afirmação errônea na qual se tem total confiança, visto que ela foi contaminada por um vírus epistemológico indetectável?

55. Acreditar ou confiar no enunciado verbal "A cloroquina é eficaz no combate ao vírus" não é terse apropriado de um saberfazer falso ou verdadeiro acerca do poder da hidroxicloroquina no combate ao vírus. Acreditar ou confiar num enunciado verbal $\mathrm{H}$ não é um saberfazer efetivo sobre aquilo que tal enunciado expressa. Só práticas efetivas que submetam $\mathrm{H}$ a provas empírico-probabilísticas podem produzir saberes-fazeres efetivos quasiinequivocos acerca do poder performativo de $\mathrm{H}$.

56. Quando usamos um enunciado como uma crença, nós fazemos dele um uso dogmático, metafísico. Nós o tornamos indubitável, significando-o como um enunciado não passível de comprovação empírico-praxiológica, mesmo que ele o seja. Nós o significamos como enunciados do tipo "Deuses existem" ou "Deuses não existem". Quando, em um jogo de linguagem, orientamos as nossas ações por uma crença, elas se deixam orientar por um não-saberfaz̧er, ainda que essa crença possa adquirir o estatuto de um saberfazer em outro jogo de linguagem.

${ }^{22}$ Comentário baseado na passagem IF-124 de Wittgenstein (s/d, IF-124). 
57. "Vem, vamos embora que esperar não é saber. Quem sabe faz a hora não espera acontecer" ${ }^{\prime 23}$. Apenas quem sabe faz! Apenas quem faz mostra um saber!

58. "Eu acreditei que sabia" é diferente de "Eu sei". A garantia de alguém confiável, dada quando diz saber, não pode auxiliá-lo nesse sentido. Seria extraordinário se tivéssemos de acreditar em alguém supostamente confiável que nos dissesse: "Eu não posso errar"; ou garantisse: "Eu não erro"24.

59. Não é confiável acreditar em alguém que diz “Aprendi comigo mesmo". Aprender é sempre uma prática interativa (como toda prática): um saberfazer orientado não apenas por crenças, mas também por enunciados mobilizados como certezas situadas em diversos jogos de linguagem. Uma certeza é um enunciado do qual escolhemos não duvidar.

60. Podemos abandonar uma ou mais crenças, mas não podemos abandonar todas as nossas crenças.

61. Um habitante de um país sem fronteiras chamado matemática aplicada, anunciou ter construído um modelo adequado para a descrição estatística do comportamento do vírus que funciona bem para todos os países envolvidos com a pandemia. O modelo provavelmente baseia-se na crença de que o vírus deve se comportar em conformidade às regras da gramática que orientou a construção do modelo, sendo tal crença uma das regras dessa gramática. Uma outra crença que integra essa gramática é a de que o vírus deveria se comportar da mesma maneira, qualquer que seja o território no qual ele adentra. Um etnomatemático, supostamente um dissidente do movimento da modelagem matemática, poderia questionar: "[...] é o vírus que deve se comportar em conformidade à gramática normativa do modelo genérico ou seriam os modelos, tantos quantas forem as culturas adentradas pelo vírus, que deveriam se comportar em conformidade à gramática normativa que orienta a disseminação do vírus? O vírus poderia responder: "Caminho [anarquicamente] contra o vento, sem lenço, sem documento" 25 e sem gramática que oriente o meu comportamento. Para onde você quiser me levar, eu vou.

62. Jamais se vira peste tão fatal e tão terrível quanto a Morte Rubra. O sangue era a sua marca: a vermelhidão e o horror do sangue. A peste vinha com dores agudas e súbitas vertigens, seguindo-se a profusa sangria pelos poros e a decomposição. As manchas escarlates no corpo, sobretudo no rosto, eram o anátema da peste e privavam seus portadores do auxílio e da simpatia de seus semelhantes. A irrupção, progresso e término da doença não duravam mais de meia hora. No palácio do Príncipe Próspero ouviu-se um grito agudo seguido da queda de uma adaga cintilante sobre o negro tapete onde tombou o Príncipe... Recorrendo à coragem selvagem do desespero, numerosos foliões agarraram o mascarado que o assasinara e pararam, arfantes de indizível pavor, ao perceber que nenhuma forma tangível se encontrava por trás da sua máscara. Nesse momento reconheceram a Morte Rubra que ali penetrara, como um ladrão noturno ${ }^{26}$.

\footnotetext{
${ }^{2}$ Versos da canção Pra Não Dižer Que Não Falei Das Flores, de Geraldo Vandré, cuja letra pode ser integralmente acessada no site (https://www.letras.mus.br/geraldo-vandre/46168/), Acesso em: 20 maio 2020.

${ }^{24}$ Segmento construído a partir de Wittgenstein (2005, SC-21 e SC-22).

${ }^{25}$ Versos da canção Alegria Alegria de Caetano Veloso.

${ }^{26}$ Segmento composto a partir de A máscara da morte rubra de Edgar Allan Poe (POE, 2008).
} 
63. Há muitas maneiras de humanos descreverem e de se comportarem diante de uma epidemia, imagens bélicas têm-se mostrado hegemônicas e persistentes. Veja esta réplica de uma adaga medieval templária com bainha ${ }^{27}$. Veja a cruz - o selo dos cavaleiros da ordem Pauperes commilitones Christi Templique Salomonici - na extremidade circular do seu cabo. - Veja também que a outra extremidade do cabo forma com a lâmina uma cruz. - Só que, nas adagas originais, a cruz era rubra, e não prateada, como aparece nesta réplica. - E o que isso tem a ver com epidemias? - Tem a ver com um certo modo como você conta um conto $^{28}$. E como quem conta um conto sempre aumenta um ponto, despertou-me a curiosidade ver como era uma das armas usadas pelos templários em suas guerras santas travadas contra os muçulmanos. Eles acreditavam estar lutando, em nome de um deus, contra outro deus. Era uma luta entre deuses mascarados de humanos. - Ou então, de humanos mascarados de deuses.

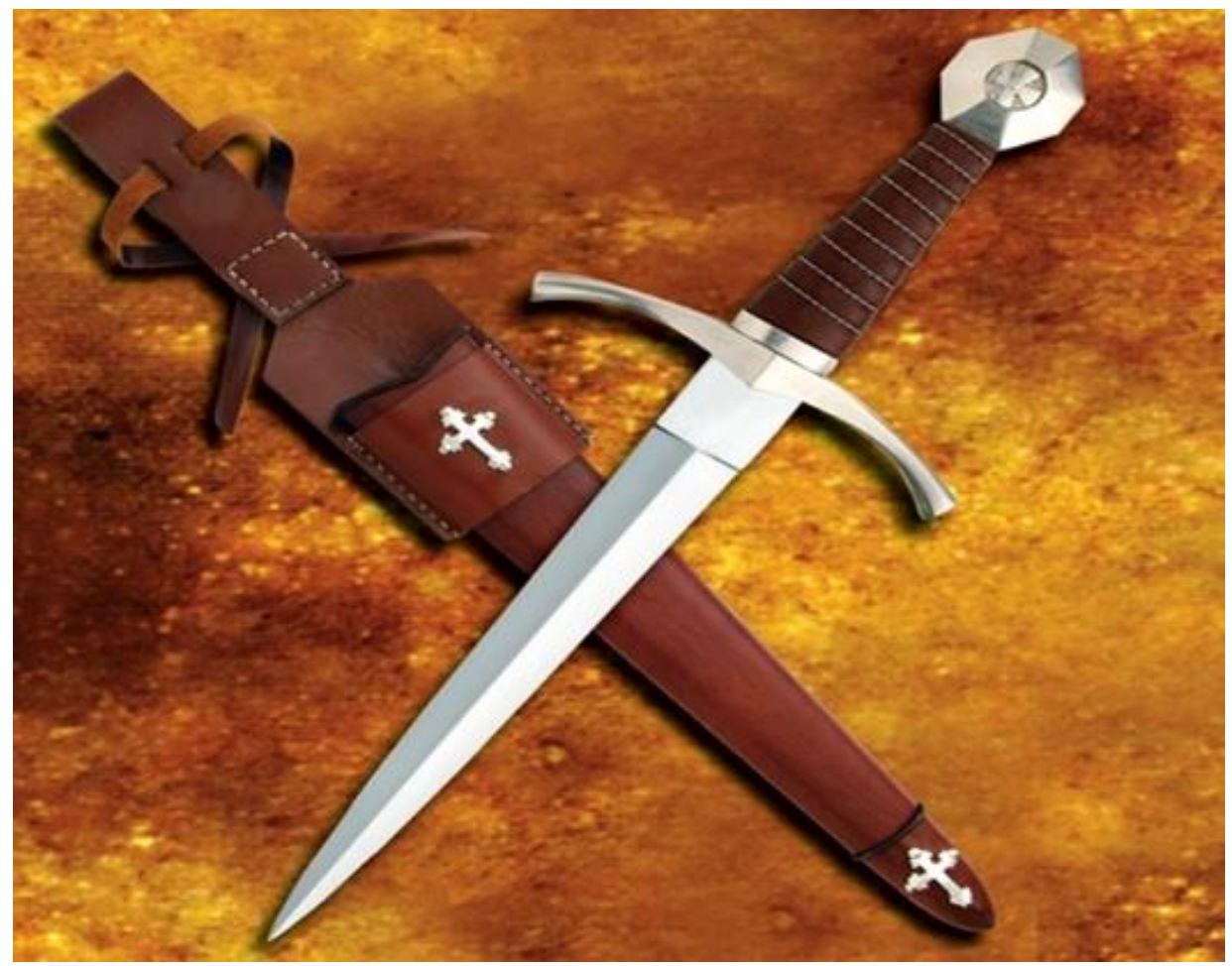

64. "A doença é o lado sombrio da vida, uma espécie de cidadania mais onerosa. Todas as pessoas vivas têm dupla cidadania, uma no reino da saúde e outra no reino da doença. Embora todos prefiram usar somente o bom passaporte, mais cedo ou mais tarde cada um de nós será obrigado, pelo menos por um curto período, a identificarse como cidadão do outro país". [...] "Meu ponto de vista é que doença não é uma metáfora e que a maneira mais honesta de encará-la - e a mais saudável de ficar doente - é aquela que esteja mais depurada de pensamentos metafóricos, que seja mais resistente a tais pensamentos" 29 .

\footnotetext{
${ }^{27}$ Imagem modificada pelos auotres a partir de fotos de réplicas de adagas.

${ }^{28}$ A voz está se referindo ao conto já citado, A máscara da morte rubra.

${ }^{29}$ Sontag $(1984$, p. 4).
} 
65. Vírus vêm e vão... vêm em vão... não bem como as estações do ano, como as colheitas, como a lua ou a covardia. Mas como a paixão e o fogo... ${ }^{30}$

66. "[...] ao ouvir os gritos de alegria que vinham da cidade, o doutor Rieux lembrava-se de que essa alegria estava sempre ameaçada. Porque ele sabia o que essa multidão eufórica ignorava e que se pode ler nos livros: o bacilo da peste não morre nem desaparece nunca, pode ficar dezenas de anos adormecido nos móveis e na roupa, espera pacientemente nos quartos, nos porões, nos baús, nos lenços e na papelada. E sabia, também, que viria talvez o dia em que, para desgraça e ensinamento dos homens, a peste acordaria seus ratos e os mandaria morrer numa cidade feliz" ${ }^{31}$.

67. "A probabilidade de uma hipótese é medida pelo número de indícios necessários para tornar vantajoso abandoná-la. É só nesse sentido que podemos dizer que a experiência uniforme repetida no passado torna provável a continuação dessa uniformidade no futuro. Se digo: 'suponho que o sol nascerá novamente amanhã, porque o contrário é muito improvável', quero dizer com 'provável' e 'improvável' algo completamente diferente de 'É igualmente provável que tirarei cara ou coroa” ${ }^{\text {32. }}$.

68. “[...] o Dr. Rieux decidiu, então, redigir esta narrativa, que termina aqui, para não ser daqueles que se calam, para depor a favor dessas vítimas da peste, para deixar ao menos uma lembrança da injustiça e da violência que lhes tinham sido feitas e para dizer simplesmente o que se aprende no meio dos flagelos: que há nos homens mais coisas a admirar do que coisas a desprezar" ${ }^{33}$.

Only when we know - and it is a knowledge gained by taking pains, by renuncing what Freud calls instinctual gratification - what we are flaing when we read, are we free to enjoy what we read. As long as our enjoyment is - or is said to be - instinctive it is not enjoyment, it is terrorism.

Richard Howard (HOWARD, 2002, p. vii)

\section{Referências}

BARTHES, Roland. S/Z. Tradução de R. Miller. Prefácio de R. Howard. UK: Blackwell, 2002.

CAMUS, Albert. A peste. Tradução de V. Rumjanek. São Paulo: Record, 2017.

DIDEROT, Denis.; D’ALEMBERT, Jean Le Rond. Enciclopédia, ou Dicionário

razoado das ciências, das artes e dos ofícios. Tradução de Fúlvia Moretto e Maria das Graças de Souza. 1. ed. São Paulo: Editora Unesp, 2015.

HOWARD, Richard. Note on S/Z. In: BARTHES, R. S/Z. Prefácio. Tradução de R. Miller. UK: Blackwell, 2002.

\footnotetext{
${ }_{30}$ Paráfrase de verso da canção Caça à raposa, de Aldir Blanc (1946-2020), vítima da pandemia, a quem dedicamos este artigo. 31 Último parágrafo do romance $A$ peste (CAMUS, 2017). Evoquemos que na França, ao fim da epidemia nažista, as pessoas retomavam, indiferentes, o seu antigo normal.

32 Wittgenstein (2005, OF-229).

${ }^{33}$ Antepenúltimo parágrafo de $A$ peste de Camus (2017), romance que se inicia com a seguinte epígrafe do escritor inglês Daniel Defoe (1660-1731): “É tão válido representar um modo de aprisionamento por outro, quanto representar qualquer coisa que de fato existe por alguma coisa que não existe".
} 
JODELET, Denise. Loucuras e representações sociais. Petrópolis: Vozes, 2005.

NOËL, Émile. As ciências da forma hoje. Tradução de C. K. Moreira. Campinas: Papirus, 1996.

POE, Edgar. A. A máscara da morte rubra. In: POE, E. A. Histórias extraordinárias. São Paulo: Companhia das Letras, 2008.

SONTAG, Susan. Doença como metáfora. Tradução de M. Ramalho. Rio de Janeiro: Edições Graal, 1984.

WITTGENSTEIN, Ludwig. Cultura e valor. Tradução de J. Mendes. Revisão de A. Morão. Lisboa: Edições 70, 2000.

Tratado Lógico-Filosófico \& Investigações Filosóficas. Tradução de M. S. Lourenço. Lisboa: Fundação Calouste Gulbenkian, 2002.

Observações filosóficas. Tradução de A. Sobral e M. S. Gonçalves. São Paulo: Edições Loyola, 2005.

Da certeza. Tradução de M. E. Costa. Lisboa: Edições 70, 2012.

Investigações filosóficas/Philosophische untersuchungen. Edição bilingue alemão/português. Tradução e notas de J. J. R. L. de Almeida. :Wittgenstein Translations, s/d. Disponível em: <http://www.psicanaliseefilosofia.com.br/textos/>. Acesso abr. 2020: 